\author{
MAGDALENA WASYLKOWSKA-MICHÓR \\ ORCID: 0000-0002-5810-9186 \\ Uniwersytet Zielonogórski \\ m.wasylkowska-michor@wpa.uz.zgora.pl
}

\title{
Współpraca państw członkowskich UE w sprawach cywilnych w obszarze poszukiwania prawa właściwego zobowiązaniom pozaumownym w latach 1957-1997
}

Przedmiotem niniejszego artykułu jest przedstawienie procesu kształtowania się współpracy państw członkowskich Unii Europejskiej w sprawach cywilnych w okresie od 1957 do 1997 roku, to jest od momentu podpisania w dniu 25 marca 1957 roku w Rzymie Traktatu ustanawiającego Europejską Wspólnotę Gospodarczą (dalej: TEWG) ${ }^{1}$ do momentu podpisania w dniu 2 października 1997 roku w Amsterdamie traktatu amsterdamskiego ${ }^{2}$. Już na wstępie należy jednakże poczynić zastrzeżenie, że rozwój tej współpracy przedstawiony został na przykładzie ujednolicania rozwiązań prawnych w jednej tylko dziedzinie prawa cywilnego, a mianowicie prawa prywatnego międzynarodowego. Wybór ten nie jest przypadkowy. $Z$ jednej bowiem strony, przynajmniej w początkowej fazie rozwoju współpracy państw członkowskich w sprawach cywilnych, regulacje traktatów konstytuujących najpierw Europejską Wspólnotę Gospodarczą, a potem Unię Europejską, nie dawały podstawy prawnej do bardziej zaawansowanych działań

1 Oficjalny tekst traktatu znajduje się na stronie internetowej: https://eur-lex.europa.eu/legal-content/PL/TXT/?uri=CELEX:11957E/TXT.

2 Traktat z Amsterdamu zmieniający Traktat o Unii Europejskiej, traktaty ustanawiające Wspólnoty Europejskie i niektóre związane z nimi akty (tak zwany traktat amsterdamski) z dnia 1 maja 1999 roku (Dz.Urz. UE z 2004 r. Nr 90, poz. 864/31). Oficjalny tekst traktatu (Official Journal C 340, z 10.11.1997, P. 0001-0144) znajduje się na stronie internetowej: https://eur-lex.europa. eu/legal-content/PL/TXT/?uri=CELEX:11997D/TXT. 
niż tylko ewentualne zbliżanie ustawodawstw bądź też ujednolicania norm kolizyjnych za zasadzie dobrowolnego przystępowania do konwencji międzynarodowych. Z drugiej natomiast strony współpraca państw członkowskich w zakresie ujednolicania przepisów prawa materialnego cywilnego w zasadzie zawsze była skazana na niepowodzenie, przede wszystkim ze względu na zbyt duże różnice pomiędzy systemami prawnymi państw członkowskich, zwłaszcza w odniesieniu do systemu prawnego common law oraz systemu kontynentalnego ${ }^{3}$. Z kolei jeśli chodzi o proces ujednolicania przez państwa członkowskie norm kolizyjnych, na szczególną uwagę, zdaniem autorki, zasługuje przedstawienie tego procesu na przykładzie ujednolicania prawa właściwego zobowiązaniom pozaumownym. Proces ujednolicania tych norm w pełni odzwierciedla bowiem równoległe kształtowanie się coraz bardziej zaawansowanych form współpracy w sprawach cywilnych w obrębie Unii Europejskiej.

Poza zakresem niniejszego opracowania pozostaje natomiast historia współpracy państw członkowskich odnośnie do ujednolicania przepisów proceduralnych, jako że względu na inny przedmiot regulacji wymaga ona odrębnego omówienia.

\section{Współpraca w sprawach cywilnych przewidziana w Traktacie ustanawiającym Europejską Wspólnotę Gospodarczą}

W dniu 25 marca 1957 roku w Rzymie podpisany został Traktat ustanawiający Europejską Wspólnotę Gospodarczą (EWG), który zapoczątkował integrację europejską w obszarze współpracy gospodarczej ${ }^{4}$. Projektodawcy TEWG nie przewidywali jednakże uregulowania w nim zagadnień współpracy sądowej ani w dziedzinie prawa cywilnego, ani tym bardziej w dziedzinie prawa karnego. Zgodnie z poglądem panującym w latach pięćdziesiątych $\mathrm{XX}$ wieku wśród przedstawicieli praktyki i doktryny prawniczej, jak również wśród polityków zagadnienia te są tak ściśle związane z władztwem państwowym, że kraje powinny zachować pełną swobodę regulacji w tym zakresie 5 .

${ }^{3}$ Nieudane były na przykład próby stworzenia europejskiego kodeksu cywilnego, którego fragmenty pozostały do dzisiaj wyłącznie projektami akademickimi, przykładowo Zasady europejskiego prawa czynów niedozwolonych (Principles of European Tort Law) opracowane przez Europejską Grupę ds. Czynów Niedozwolonych.

4 Traktat wszedł w życie 1 stycznia 1958 roku.

5 Unia Europejska. Prawo instytucjonalne i gospodarcze, red. A. Grzelak, B. Wawrzyńczak-Jędryka, Warszawa 2005, s. 1216-1217. 
Jedyne odniesienie do tej materii zostało zawarte w art. 220 (293) Traktatu o Wspólnocie Europejskiej (dalej: TWE) ${ }^{6}$, który przerzucał ciężar działań w tym zakresie na państwa członkowskie i stanowił, że w miarę potrzeby podejmują one między sobą rokowania w celu zapewnienia swoim obywatelom uproszczenia formalności dotyczących wzajemnego uznawania i wykonywania orzeczeń sądowych i arbitrażowych. Celem tych umów powinno być przy tym osiągnięcie jednego $\mathrm{z}$ czterech celów wymienionych w treści tego przepisu?

Na tle stosowania tego artykułu powstała jednak wątpliwość, czy podejmowanie negocjacji przez państwa jest obligatoryjne. Wynikałoby to z dosłownej treści przepisu, zwłaszcza w jego wersji angielskiej (shall enter into negotiations). Z kolei wyrażenie „w miarę potrzeby" wskazuje na charakter ocenny podejmowanych przez państwa kroków. Według M. Szpunara decyzja o podjęciu negocjacji powinna, zgodnie z takim przepisem, należeć do państwa, lecz ewentualny obowiązek w praktyce byłoby bardzo trudno udowodnić i wyegzekwować ${ }^{8}$. Ponadto przepis ten nie opowiedział się wyraźnie za tym, czy zawierane na jego podstawie konwencje mają służyć ujednoliceniu prawa, jak również pozostawił międzyrządowe negocjacje państw członkowskich praktycznie bez nadzoru Wspólnoty9. Jak zatem widać, twórcy TEWG przewidzieli w zakresie współpracy w sprawach cywilnych i handlowych utrzymanie tradycyjnego narzędzia prawa międzynarodowego publicznego, to jest negocjacji międzynarodowych prowadzących do zawarcia umowy międzyrządowej i następnie jej ratyfikacji ${ }^{10}$.

Następna wątpliwość, jaka się pojawia, to czy wszystkie państwa, które są stronami konwencji zawartych na podstawie art. 220 (293) TWE, muszą być jednocześnie państwami członkowskimi UE. W ocenie M. Szpunara istnieje taki obowiązek, ponieważ w przeciwnym razie nie stanowiłyby one instrumentów usuwających przeszkody w funkcjonowaniu wolnego rynku ${ }^{11}$.

Współpraca państw członkowskich w sprawach cywilnych w tamtym okresie istniała zatem tylko w obszarze prawa międzynarodowego publicznego. Co więcej, aby mogły wejść w życie, konwencje zawarte na podstawie art. 220 (293) TWE musiały być ratyfikowane przez określoną liczbę państw członkowskich, aczkol-

${ }^{6}$ W 1992 roku na podstawie traktatu z Maastricht (Traktatu o Unii Europejskiej), podpisanego 7 lutego 1992 roku (wejście w życie 1 listopada 1993 roku; Dz.U. C 191 z 29.07.1992, s. 1-112), zmieniono nazwę EWG na Wspólnota Europejska.

7 J. Basedow, The communitarization of the conflict of laws under the Treaty of Amsterdam, „Common Market Law Review” 37, 2000, s. 687.

${ }^{8}$ M. Szpunar, [w:] Komentarz do Traktatu ustanawiającego Wspólnotę Europejska, red. A. Wróbel, t. 3, Warszawa 2010, s. 907. Wydaje się też, że kwestia ta została rozstrzygnięta również w orzecznictwie Trybunału; por. wyrok Trybunału Sprawiedliwości z dnia 5 listopada 2002 roku, Überseering BV a Nordic Construction Company Baumanagement GmbH (NCC), C-208/00.

9 J. Basedow, op. cit., s. 687-690.

${ }^{10}$ M. Fabjańska, M. Świerczyński, Ujednolicenie norm kolizyjnych dotyczacych zobowiazań pozaumownych, „Kwartalnik Prawa Prywatnego” 2004, nr 3, s. 717-718.

11 M. Szpunar, op. cit., s. 907. 
wiek zakładały możliwość składania zastrzeżeń. Trybunał Sprawiedliwości nie mógł ich jednak kontrolować ani interpretować ${ }^{12}$.

Pojawia się więc pytanie, czy zawarte w tym okresie konwencje można w ogóle uznać za część wspólnotowego porządku prawnego, a jeśli tak, to czy zaliczają się one do pierwotnego czy pochodnego prawa wspólnotowego. M. Szpunar uważa, że są one przyjmowane przez państwa członkowskie, a nie przez instytucje wspólnotowe, a poza tym są zawierane w wykonaniu normy traktatowej i muszą być zgodne z podstawą traktatową. Należy je tym samym uznać za część prawa pochodnego. Norma traktatowa powinna mieć także pierwszeństwo w przypadkach kolizji między nią a normą konwencyjną ${ }^{13}$.

W okresie tym podpisane zostały: Konwencja brukselska (Bruksela I) dotycząca jurysdykcji i wykonywania wyroków w sprawach cywilnych i handlowych $^{14}$, która została przeniesiona do Konwencji z Lugano ${ }^{15}$ dotyczącej stosunków z państwami niebędącymi członkami UE, a także Konwencja rzymska o prawie właściwym dla zobowiązań umownych ${ }^{16}$

\subsection{Pierwsze próby ujednolicenia prawa właściwego zobowiązaniom pozaumownym}

Podczas II wojny światowej znany niemiecki adwokat Ernst Frankenstein opracował, na angielskiej emigracji, własny projekt europejskiego prawa prywatnego międzynarodowego, który został opublikowany w Holandii w 1950 roku, w języku francuskim, pod tytułem Projet d'un Code Européen de droit international privé. To pierwsze europejskie, całościowe opracowanie, które w 816 artykułach zawierało całe prawo kolizyjne, jak również procedurę, w tym postępowanie przed sądami arbitrażowymi, oraz prawo upadłościowe. Niestety przeszło niezauważone. W zakresie czynów niedozwolonych projekt zawierał regulacje kolizyjną dla wszystkich typów zobowiązań pozaumownych (od art. 530 do art. 542 oraz art. 628). Rozwiązania przyjęte w opracowaniu opierały się na tradycyjnej zasadzie prawa miejsca czynu (lex loci delicti commissi), lecz uwzględniały także

\section{Ibidem.}

13 Ibidem.

14 Rozporządzenie Rady (WE) nr 44/2001 z dnia 22 grudnia 2000 roku w sprawie jurysdykcji i uznawania orzeczeń sądowych oraz ich wykonywania w sprawach cywilnych i handlowych (Dz. Urz. WE L 12 z 16.01.2001, s. 1; polskie wydanie specjalne: t. 4, rozdział 19, s. 42-64).

15 Konwencja o jurysdykcji i wykonywaniu orzeczeń sądowych w sprawach cywilnych i handlowych, sporządzona w Lugano dnia 16 września 1988 roku (Dz.U. z 2000 r. Nr 10, poz. 132).

16 Konwencja o prawie właściwym dla zobowiązań umownych z dnia 19 czerwca 1980 roku (Dz.Urz. UE C 334 z 30.12.2005, s. 3 n.). 
wyjątki na rzecz miejsca zwykłego pobytu stron oraz przewidywały możliwość wyboru prawa przez poszkodowanego ${ }^{17}$.

Pierwszą zinstytucjonalizowaną, wychodzącą poza ramy prywatnego projektu, próbą stworzenia wspólnych norm kolizyjnych była Konwencja państw Beneluksu ujednolicająca niektóre kwestie prawa prywatnego międzynarodowego, która została zawarta dnia 11 maja 1951 roku. Prawo właściwe zobowiązaniom pochodzącym z czynów niedozwolonych zostało w niej określone według zasady lex loci delicti commissi (art. 18 ust. 1). Gdy skutki czynu niedozwolonego wystąpiły jednak na terenie innego kraju niż ten, w którym czyn został popełniony, konsekwencje prawne tego czynu były wskazywane według prawa pierwszego z tych państw (art. 18 pkt 2). Co więcej, konwencja uwzględniała również prawo wspólnego miejsca zamieszkania stron. Jako uzasadnienie tej ostatniej opcji Raport Stałego Komitetu Beneluksu podawał w tym miejscu przypadek zderzenia się przy granicy dwóch samochodów używanych i będących jednocześnie własnością osób mieszkających w kraju sąsiednim, których to wypadków było bardzo dużo w pobliżu granicy belgijsko-luksemburskiej. Skutki prawne takiego wypadku były zawsze określane zgodnie z prawem miejsca zamieszkania obydwu stron ${ }^{18}$. Konwencja nigdy nie weszła w życie ze względu na brak wymaganej liczby podpisów.

Już w 1967 roku we Wspólnocie przystąpiono do kolejnej próby kodyfikacji norm kolizyjnych. W liście datowanym na 8 września 1967 roku Joseph Van Der Meulen, stały przedstawiciel Belgii w Komisji Europejskiej, wystąpił do Komisji z inicjatywą zorganizowania współpracy ekspertów z państw członkowskich w celu zunifikowania prawa prywatnego międzynarodowego w obrębie Wspólnoty. Zaproszenie to było pochodną wspólnej inicjatywy rządów Belgii, Holandii i Luksemburga, których połączone wysiłki w tym obszarze zaowocowały w 1951 roku konwencją Beneluksu dotyczącą prawa prywatnego międzynarodowego. Jako podstawę prawną twórcy projektu bezsprzecznie przyjęli art. 220 TEWG — tak jak

17 K.F. Kreuzer, Die Vergemeinschaftung des Kollisionsrechts für ausservertragliche Schuldverhältnisse (Rom II), [w:] Europäisches Kollisionsrecht, red. E. Jayme et al., Wien 2004, s. 18 19. $\mathrm{Z}$ analizy rozwiązań przyjętych w projekcie wynika zatem, że twórca tej konwencji dostrzegał już konieczność uelastycznienia sztywnej reguły kolizyjnej, wprowadzając nie tylko wyjątek na rzecz miejsca wspólnego pobytu, lecz także rewolucyjną w tamtym okresie zasadę wyboru prawa przez strony.

18 E.M. Meijers, The Benelux Convention on private international law, „American Journal of Comparative Law" 2, 1953, s. 9. Mimo że konwencja państw Beneluksu nigdy nie weszła w życie, była w tych czasach zaskakująco nowoczesnym rozwiązaniem. Wynika z tego wyraźnie, że jej zasada ogólna opierała się na zasadzie prawa właściwego miejscu działania, jednakże konwencja jednocześnie zawierała szeroko zakrojoną klauzulę wyjątkową, obejmującą transgraniczne czyny niedozwolone, w których wypadku konsekwencje działania w jednym kraju stanowią szkodę w drugim. Ponadto wydaje się, że twórcy tej konwencji podjęli w niej próbę zrównoważenia interesów strony powodowej i pozwanej. W przypadku deliktów, które zamykają się w obrębie jednego państwa, zarówno powód, jak i pozwany są świadomi, gdzie nastąpi jednocześnie działanie i skutek. Z kolei w drugim przypadku twórcy konwencji ze względu na przypadkowość miejsca wystąpienia szkody uwzględnili interes poszkodowanego. 
w wypadku konwencji brukselskiej o uznawaniu i wykonywaniu orzeczeń, której projektowana konwencja miała być naturalną kontynuacją, chociaż ten artykuł nie zawierał żadnego odniesienia do szerszej harmonizacji bądź też ujednolicenia prawa międzynarodowego prywatnego ${ }^{19}$.

Zgodnie $\mathrm{z}$ art. 1 projektu konwencji zasady prawa prywatnego międzynarodowego w niej wyrażone stosuje się do zobowiązań umownych i pozaumownych w sytuacjach o międzynarodowym charakterze ${ }^{20}$. Nie mają one natomiast zastosowania do: (1) statusu prawnego, zdolności prawnej, jak również do małżeńskich ustrojów majątkowych, dziedziczenia, testamentów albo darowizn; (2) papierów wartościowych, takich jak weksle, czeki albo skrypty dłużne; (3) umów o arbitraż i dotyczących wyboru sądu; (4) umów ubezpieczenia; (5) ustanowień, wewnętrznych procedur działania i rozwiązania przedsiębiorstw bądź też innych osób prawnych oraz (6) szkód jądrowych. Ponadto konwencja nie miała zastosowania do odpowiedzialności państwa ani innych osób prawnych prawa publicznego (jednostek państwowych), jak również ich organów lub przedstawicieli za czyny z zakresu władztwa publicznego popełnione przez organy bądź też ich przedstawicieli

19 Komisja przeprowadziła w 1969 roku dwa spotkania ekspertów, z których pierwsze miało miejsce w dniach 26-28 lutego. Było ono poświęcone analizie rozprowadzonego wcześniej w państwach członkowskich kwestionariusza dotyczącego kierunków, w których mają pójść prace. Na drugim spotkaniu grupa ekspertów poczyniła rekomendacje co do dziedzin, na których powinna się skupić dalsza praca, a które są ściśle związane z właściwym funkcjonowaniem wspólnego rynku, to jest na: (1) prawie właściwym własności materialnej i niematerialnej, (2) prawie właściwym zobowiązaniom umownym i pozaumownym, (3) prawie właściwym formom transakcji prawnych i dowodów, (4) ogólnych zasadach prawa prywatnego międzynarodowego dotyczących następujących zagadnień: renvoi, klasyfikacja, stosowanie prawa obcego, prawa nabyte, klauzula porządku publicznego, zdolność prawna, reprezentacja (przedstawicielstwo). Na spotkaniu 15 stycznia 1970 roku Komitet Stałych Przedstawicieli oficjalnie upoważnił grupę do kontynuowania pracy nad ujednoliceniem norm prawa prywatnego międzynarodowego przy założeniu, że wstępny projekt powinien skupiać się na czterech uprzednio wskazanych obszarach. Po przystąpieniu do EWG Zjednoczonego Królestwa, Danii i Irlandii w 1973 roku Komisja rozszerzyła grupę, włączając w nią ekspertów z nowych państw członkowskich, przy czym niepewna pozycja Wielkiej Brytanii w EWG wstrzymała w praktyce prace aż do 1975 roku, kiedy to wynik referendum przeprowadzonego w tym kraju rozstrzygnął o jego pozostaniu we Wspólnocie. Ostateczny projekt konwencji był gotowy w 1978 roku, wówczas grupa zadecydowała bowiem o jego ograniczeniu tylko do rozwiązań dotyczących prawa właściwego zobowiązaniom umownym. Zob. Report on the Convention on the law applicable to contractual obligations, sporządzony przez M. Giuliano, profesora Uniwersytetu w Mediolanie, oraz P. Lagrade, profesora Uniwersytetu w Paryżu (Dz.Urz. WE C 282 z 31.10.1980, s. 1-6).

20 Odnośnie do tego sformułowania w toku prac nad projektem powstała wątpliwość co do kwestii zastosowania rozwiązań konwencji w sprawach o charakterze czysto wewnętrznym. W końcu ostatecznie przyjęto, że sprawa „o charakterze międzynarodowym” to tylko ta, w której prawo właściwe jest prawem państwa innego niż to, w którym znajduje się sąd rozstrzygający sprawę. Zob. B. von Hoffman, O. Lando, K. Siehr, European Private International Law of Obligations. Acts and Documents of an International Colloquium on the European Preliminary Draft Convention on the Law Applicable to Contractual and Non-Contractual Obligations, Tübingen 1975, s. 48-49. 
w wykonywaniu ich oficjalnych funkcji ${ }^{21}$. Konwencja miała z kolei zastosowanie, nawet jeśli wskazane prawo właściwe nie było prawem państwa strony (art. 1) 22 .

Główna zasada dotycząca prawa właściwego czynom niedozwolonym została wyrażona w art. 10 konwencji, zgodnie z którym zobowiązania pozaumowne wynikające ze zdarzenia powodującego szkodę powinny podlegać prawu państwa, w którym doszło do wystąpienia zdarzenia (pkt 1)23. Jakkolwiek, jeśli z jednej strony nie istniało żadne znaczące powiązanie między sytuacją wynikającą ze zdarzenia, które spowodowało szkodę, a państwem, w którym nastąpiło to zdarzenie, bądź też jeśli z drugiej strony taka sytuacja miała znacznie ściślejszy związek z innym państwem, powinno się stosować prawo tego państwa (pkt 2). Ponadto z pkt 3 wynikało domniemanie, że taki związek musi być oparty na łączniku wspólnym dla sprawcy szkody i poszkodowanego, a jeśli w grę wchodzi odpowiedzialność osoby trzeciej — na czynniku wspólnym dla poszkodowanego i tej osoby trzeciej. Projekt konwencji zawierał zatem oddzielne normy dla (1) pozaumownej odpowiedzialności wynikającej ze „zdarzenia, którego skutkiem była szkoda lub uszczerbek" (w oryginalnej francuskiej wersji un fait dommageable) i (2) pozaumownych zobowiązań wynikających ze ,zdarzenia, którego skutkiem nie jest szkoda ani uszczerbek" (un fait autre qu'un fait dommageable). Jeśli zaś chodzi o pkt 2, to konwencja ustanawiała tu dwa warunki: znaczący związek (significant link) między czynem niedozwolonym a miejscem jego wystąpienia, jak również wymóg, aby ta sytuacja miała jednocześnie ,ściślejszy związek” z innym państwem ${ }^{24}$.

21 Ibidem, s. 45-46.

22 K.H. Nadelmann, The EEC Draft of a Convention on the law applicable to contractual and non-contractual obligations, „American Journal of Comparative Law” 2, 1973, s. 587-589.

${ }^{23}$ Co do sformułowania zasady głównej podkreślano, że co prawda przyjęty w niej łącznik lex loci delicti commissi to jedyny precyzyjny łącznik w całym akcie prawnym, jednakże nie rozwiązuje on problemów w przypadku tak zwanych deliktów popełnianych na odległość, to znaczy takich, kiedy czyn zostanie popełniony w jednym kraju, a do wystąpienia skutku dojdzie w innym (zob. B. von Hoffman, O. Lando, K. Siehr, op. cit., s. 48-49). Wydaje się jednak, że intencją twórców projektu było to, aby pojęciem najściślejszego związku był również objęty związek z prawem miejsca, w którym doszło do wystąpienia szkody. Następnie podnoszono także wątpliwości, czy lex loci delicti commissi powinno być w ogóle zasadą ogólną. Jako rozwiązania alternatywne prezentowane były między innymi zasady proper law of the tort, „najbardziej znaczącego związku” (most significant relationship) bądź też „centrum ciężkości” (center of gravity) oraz koncepcja stosowania innego prawa właściwego w zależności od rodzaju czynu niedozwolonego. Nikt jednak ostatecznie nie podważył w toku dyskusji zasady lex loci delicti commissi (zob. ibidem, s. 48-50). W końcu na gruncie projektu konwencji problematyczna stała się też kwestia nieokreślenia prawa właściwego oddzielnie co do poszczególnych typów czynów niedozwolonych (szerzej na ten temat zob. ibidem, s. 55; oraz K.H. Nadelmann, Impressionism and unification of law: The EEC Draft Convention on the law applicable to contractual and non-contractual obligations, „American Journal of Comparative Law" 24, 1976, s. 12-15).

24 A. Dickinson, The Rome II Regulation: The Law Applicable to Non-Contractual Obligations, Oxford 2009, s. 26-27. 
Konwencja dawała przy tym wskazówkę, że z reguły taki związek powinien być oparty na łączniku wspólnym dla poszkodowanego i sprawcy szkody bądź też jeśli w grę wchodzi odpowiedzialność osoby trzeciej — łączniku wspólnym dla poszkodowanego i osoby trzeciej (pkt 3). Jeśli było dwie lub więcej osób poszkodowanych, prawo właściwe każdej z nich powinno być określane oddzielnie (pkt 4). Zakres zastosowania prawa właściwego został określony w art. 11, który stanowił, że prawo właściwe zobowiązaniom pozaumownym na podstawie art. 10 powinno w szczególności określać: (1) warunki i zakres odpowiedzialności, przyczyny wyłączenia odpowiedzialności, jak również (2) jej ograniczenia i podział; (3) istnienie i rodzaj (charakter) szkód, za które może zostać przyznane odszkodowanie; (4) rodzaje i zakres odszkodowania; (5) zakres, do którego prawa poszkodowanego do odszkodowania mogą przechodzić na jego spadkobierców; (6) osoby, które zostały poszkodowane i mogą dochodzić odszkodowania w swoim imieniu; (7) odpowiedzialność zastępczą oraz (8) zasady przypisywania i ograniczenia odpowiedzialności, włączając $w$ to zasady odnoszące się do okresów przedawnienia tejże odpowiedzialności, zawieszenia bądź też przerwania biegu tego przedawnienia ${ }^{25}$.

Podobnie jak w wypadku projektu E. Frankensteina twórcy konwencji jako zasadę główną pozostawili lex loci delicti commissi, z tym że łącznik uzupełniający prawa miejsca wystąpienia szkody został zastąpiony klauzulą najściślejszego związku, co jest rozwiązaniem bardziej elastycznym, lecz jednocześnie strony niosącym z sobą ryzyko zmniejszenia pewności prawa. Trudno jednak na dzisiejszym etapie rozwoju prawa prywatnego międzynarodowego wyobrazić sobie, aby tradycyjne łączniki nie były w ogóle korygowane przez klauzulę najściślejszego związku. Zmniejszenie pewności prawa na pewno potęgował natomiast fakt, że projekt zakładał konieczność badania, zarówno czy nie istniało żadne znaczące powiązanie między zaistniałym stanem faktycznym a państwem, w którym doszło do zdarzenia powodującego szkodę, jak i czy nie istnieje jednocześnie znacznie ściślejszy związek z innym państwem. Takie rozwiązanie komplikuje przy tym proces określania prawa właściwego, nakładając na sąd konieczność dokonania niejako podwójnej oceny.

Równocześnie jednak wydaje się, że w istocie rozwiązanie zastosowane $\mathrm{W}$ art. $10 \mathrm{pkt} 3$ projektu jest nie mniej niejasne niż to, które zostało przyjęte $\mathrm{w}$ art. 4 ust. 3 rozporządzenia „Rzym II”. Ten ostatni artykuł jako przykład czynnika, który świadczy o zaistnieniu znacznie ściślejszego związku, wskazuje bowiem tylko „wcześniejszy stosunek pomiędzy stronami, taki jak umowa”. Z tego przepisu nie wynika również, co robić, gdy takich czynników jak umowa jest więcej, oraz czy stosunek istniejący między stronami musi mieć charakter prawny, czy może to być stosunek faktyczny. Można zatem zaryzykować twierdzenie, że kryteria te $\mathrm{w}$ istocie niczym się od siebie nie różnią.

25 K.H. Nadelmann, The EEC Draft of a Convention..., s. 587-589. 
W świetle przedstawionych danych wydaje się, że za niepowodzenie projektu w części dotyczącej właśnie czynów niedozwolonych częściowo odpowiedzialny jest niewłaściwy dobór momentu, w którym podjęte zostały te prace. Należy bowiem pamiętać, że w końcu lat sześćdziesiątych XX wieku najpierw przez Stany Zjednoczone, a później przez Europę przetaczała się prawdziwa rewolucja odnośnie do kształtu prawa kolizyjnego w ogóle, a w zakresie dotyczącym czynów niedozwolonych w szczególności, co spowodowało, że grupa robocza była niejako zdezorientowana co do ogólnej koncepcji projektu, to znaczy wahała się między podejściem tradycyjnym a nowym, próbując znaleźć jakikolwiek kompromis, który w rezultacie doprowadził do powstania jeszcze większej liczby wątpliwości. Reasumując, należy stwierdzić, że koncepcja projektu konwencji nie została dokładnie przemyślana, co dobitnie wyraził A. Dickinson, pisząc, że „podejście do prawa właściwego dola zobowiązań pozaumownych w projekcie z 1972 r. wydaje się cechować »pewną niezręcznością i brakiem wyrafinowania«"26.

\subsection{Ocena tradycyjnej metody współpracy państw w sprawach cywilnych}

Dokonując oceny tradycyjnej metody współpracy państw w sprawach cywilnych, należy wyodrębnić dwie sytuacje, a mianowicie taką, w której współpraca ta miała za podstawę art. 220 TWE (tak zwane konwencje międzynarodowe w znaczeniu ścisłym - close conventions), oraz taką, która również odbywa się drogą umów międzynarodowych, ale zawieranych według tradycyjnych metod prawa międzynarodowego publicznego.

Każda nowa konwencja przyjmowana na podstawie art. 220 TWE, aby wejść w życie, musiała być ratyfikowana przez wszystkie państwa członkowskie bez wyjątku. Forma traktatu międzynarodowego okazała się zatem zbyt uciążliwa i nieporęczna dla Wspólnoty składającej się początkowo z sześciu państw, których liczba miała stopniowo wzrastać. Każda kolejna akcesja nowego członka do UE powodowała, że konwencje brukselska i rzymska musiały być dostosowywane i ponownie ratyfikowane przez wszystkie państwa. Rosnąca liczba państw członkowskich uczyniła proces ratyfikacji coraz bardziej pracochłonnym i długotrwałym, w rezultacie czego Komisja Europejska otwarcie brała pod uwagę wprowadzenie sankcji dla państw, które nie zaaprobowały poprawek. Ponadto w niektórych $\mathrm{z}$ tych państw wymagane było przekształcenie postanowień konwencyjnych w ustawę krajową. Doświadczenie pokazuje przy tym, że osiągnięcie jednomyślności jest szczególnie trudne w dziedzinie prawa prywatnego ${ }^{27}$, a jeśli umowa w końcu została zawarta, często albo za bardzo opierała się na jednym

26 A. Dickinson, op. cit., s. 28.

27 J. Basedow, op. cit., s. 687-690. 
systemie prawnym, albo też w drodze kompromisu uciekała się do niejasnych, pustych sformułowań, powodując, że traktat wcale nie ma ujednolicającego skutku.

Następnie instytucje Wspólnoty mogły być wyłącznie inicjatorem prac, nie mogły ich oficjalnie prowadzić i nad nimi czuwać ze względu na brak kompetencji. W przeciwnym razie naruszyłyby zasadę ograniczenia kompetencji, z której wynika, że organy wspólnotowe mogą podejmować odpowiednie działania, o ile mają wyraźną kompetencję do działania na danym obszarze ${ }^{28}$. Jednocześnie jednak konwencje międzynarodowe zawierane na podstawie art. 220 TWE były podporządkowane istniejącym lub dopiero przyszłym aktom instytucji wspólnotowych, nie było w związku z tym ryzyka, że istniejący lub przyszły akt wspólnotowy spowoduje, że państwo członkowskie naruszy swoje zobowiązania w stosunku do państwa trzeciego. Jakkolwiek by było, w wypadku aktów przyszłych podporządkowanie było jednak znaczące ze względu na ich otwarty charakter ${ }^{29}$.

Z kolei jeśli chodzi o tradycyjną metodę współpracy w formie konwencji międzynarodowych, nieopartą na prawie wspólnotowym, to wydaje się ona mieć jednak więcej zalet. Nie wymaga bowiem tożsamości między byciem stroną traktatu a byciem członkiem Unii Europejskiej, w związku z czym nie jest ograniczona tylko do państw członkowskich ani nie znajduje zastosowania jedynie wtedy, gdy wszystkie państwa członkowskie staną się jej stronami. Co więcej, przedmiot regulacji mógł być wybierany znacznie swobodniej niż w obrębie Wspólnoty, ponieważ ta nie zawsze miała kompetencje do działania w danej dziedzinie. Następną korzyścią tworzenia wspólnego prawa prywatnego drogą traktatów jest możliwość, którą daje ta metoda, jeśli chodzi o dobrowolne przyłączanie się do traktatu, już po jego zawarciu, większej liczby państw. Traktaty mogą także wskazywać na możliwe obszary ujednolicania za pomocą środków wspólnotowych, jeśli przynajmniej parę państw już przyjęło do wiadomości potrzebę wypracowania wspólnych zasad i regulacji w kwestiach, których traktat dotyczy. Jest także możliwość przekształcenia umowy międzynarodowej w akt wspólnotowy, tak jak stało się to w przypadku rozporządzenia Rady nr 44/2001 z dnia 22 grudnia 2000 roku o jurysdykcji i uznawaniu wyroków w sprawach cywilnych i handlowych oraz rozporządzeniem „Rzym I”, po tym jak Wspólnota nabyła do tego kompetencji na mocy art. 65 i 67 TWE $^{30}$.

Wady obydwu metod tworzenia wspólnego prawa prywatnego międzynarodowego są jednak oczywiste, jeśli porównamy je do takich środków jak rozporządzenia i dyrektywy. Największym problemem jest wejście traktatu w życie i jego interpretacja. Żadne państwo nie ma obowiązku uczestniczenia w projektach mających na celu harmonizację i ujednolicenie prawa prywatnego. W rezultacie w przypadku zawierania poszczególnych konwencji w procesie tym mogą uczest-

28 M. Fabjańska, M. Świerczyński, op. cit., s.720.

29 R. Plender, M. Wilderspin, The European Private Law of Obligations, London 2009, s. 13-14.

30 P.C. Müller-Graf, EC Directives as a means of private law unification, [w:] Towards a European Civil Code, red. A. Hartkamp et al., Nijmegen 2004, s. 83-84. 
niczyć różne państwa, co powoduje skomplikowaną i niekorzystną sytuację, patrząc z punktu widzenia wspólnego prawa prywatnego w Unii, polegającą na tym, że jedną konwencję będzie przyjmować jedna grupa państwa, a drugą inna. Co więcej, w wypadku interpretacji postanowień umów międzynarodowych z reguły nie jest zastrzeżona żadna obowiązkowa procedura mająca na celu ujednolicenie interpretacji i zastosowanie zasad i postanowień zawartych w traktacie.

Ponadto należy zgodzić się ze stanowiskiem wyrażanym w doktrynie przedmiotu, że można w tym miejscu dodać kolejne zastrzeżenie do stosowania traktatów do unifikacji prawa prywatnego, a mianowicie że traktat z reguły nie przewiduje możliwości odwołania się do sądu, który mógłby rozwiązać problemy związane z interpretacją, co uniemożliwia prawdziwą unifikację. Podsumowując, należy stwierdzić, że unifikacja dokonywana drogą traktatów jest z reguły bardzo fragmentaryczna, jako że międzynarodowe traktaty regulują tylko bardzo ograniczony wycinek prawa prywatnego ${ }^{31}$.

\section{Uregulowanie współpracy w sprawach cywilnych w Traktacie z Maastricht}

\section{1. Środki współpracy w sprawach cywilnych przyjęte w Traktacie z Maastricht}

Za kolejny krok w rozwoju współpracy w sprawach cywilnych między państwami członkowskimi należy uznać Traktat o utworzeniu Unii Europejskiej (TUE) podpisany w Maastricht dnia 7 lutego 1992 roku, który wszedł w życie 1 stycznia następnego roku. Traktat ten, oprócz tego że stworzył ramy Wspólnoty Europejskiej, dał również podstawę do współpracy pomiędzy państwami członkowskimi w sprawach cywilnych, a mianowicie za pomocą art. K1 ust. 6 TUE, który stanowił, że do realizacji celów Unii, w szczególności swobodnego ruchu osobowego, państwa członkowskie uważają za przedmiot wspólnego zainteresowania pewne dziedziny czy kwestie, do których należała między innymi współpraca sądowa w sprawach cywilnych (pkt 6). Zgodnie zatem z treścią art. K1 ust. 6 zagadnienia współpracy sądowej w sprawach cywilnych, kiedyś pozostające w wyłącznej gestii państw członkowskich, podlegały regulacji w ramach trzeciego filaru. Należy jednakże zauważyć, że na gruncie tego filaru podstawową rolę odgrywało głosowanie w systemie głosów ważonych. Oznaczało to, że państwa te miały w większości przypadków prawo inicjatywy ustawodawczej, miały również prawo weta w stosunku do zawieranych w obrębie tego filaru aktów. Co więcej,

31 J. Smits, The Making of European Private Law, Antwerpen-Oxford-New York 2001, s. 15-21. 
w trzecim filarze współpraca państw opierała się przede wszystkim na umowach międzynarodowych. W stosunku do procedury zawierania konwencji międzynarodowych państwa były związane ogólnymi zasadami prawa międzynarodowego publicznego. Niestety większość konwencji zaproponowanych w III filarze, ze względu na niejednomyślność, nigdy nie weszła w życie, albowiem sprzeciw jednego państwa blokował cały proces zawierania takiej umowy ${ }^{32}$. Jedynym zatem aktem przyjętym na gruncie tego filaru była konwencja o jurysdykcji oraz uznawaniu i wykonywaniu orzeczeń sądowych w sprawach małżeńskich, która nie weszła jednak w życie z powodu zbyt małej liczby ratyfikacji ${ }^{33}$.

Przedstawione zmiany miały w rzeczywistości znikomy wpływ na modyfikację warunków współpracy państw członkowskich w sprawach cywilnych. Przede wszystkim nie została wyeliminowana zasada jednomyślności wszystkich państw członkowskich, jako że sprzeciw jednego państwa mógł zniweczyć wszystkie wysiłki zmierzające do przyjęcia konwencji. Nic nie zmieniło również poszerzenie katalogu środków współpracy w sprawach cywilnych o wspólne stanowiska i wspólne działania. W przypadku wspólnych stanowisk nadal wymagana była jednomyślność, a ponadto nie był jasny ich charakter prawny, albowiem nigdzie nie zapisano wprost, że mają one moc wiążącą, co z kolei zostało wprost stwierdzone w wypadku wspólnych działań. Marginalna była także rola Trybunału Sprawiedliwości - traktat w ogóle nie przewidywał jego udziału w interpretowaniu odnośnych postanowień TUE oraz kontroli działań państw.

\subsection{Wczesne prace nad projektem konwencji „Rzym II” w obrębie Rady Unii Europejskiej}

Koncepcja opracowania konwencji o prawie właściwym zobowiązaniom pozaumownym powróciła w 1996 roku, w okresie prezydencji austriackiej, kiedy to drogą uchwały z dnia 14 października 1996 roku ustanawiającej priorytety współpracy w sprawach cywilnych Rada postanowiła wszcząć dyskusję na temat możliwości opracowania takiej konwencji. Zadaniem przyszłej konwencji miało być ustanowienie kompleksowego zespołu reguł prawnych właściwych zobowiązaniom pozaumownym, to jest zobowiązań między dwiema lub więcej osobami, które nie są oparte na ważnej, obowiązującej umowie. Jeśli natomiast chodzi o zakres zastosowania terytorialnego, to podobnie jak w przypadku Konwencji rzymskiej z 1980 roku projektowana konwencja powinna mieć zastosowanie ogólne, niezależnie od tego, czy prawo właściwe jest prawem państwa strony. Jako zasadę ogólną twórcy projektu przewidzieli zasadę najściślejszego związku, to jest sto-

32 P. Saganek, Wspótpraca $w$ dziedzinie wymiaru sprawiedliwości i spraw wewnętrznych, [w:] Integracja europejska. Wybrane problemy, red. D. Milczarek, A.Z. Nowak, Warszawa 2003, s. 208-217.

33 Unia Europejska. Prawo..., s. 1216-1217. 
sowania prawa, z którym dana sytuacja faktyczna jest najściślej związana. Wzruszalne domniemanie powinno przy tym polegać na tym, że najściślejszy związek istnieje z prawem tego państwa, w którym zaszło powodujące szkodę działanie; w wypadku czynów niedozwolonych popełnionych przez zaniechanie powinno to być prawo państwa, w którym działanie powinno było mieć miejsce. Przyszła konwencja odrzucała natomiast zasadę prawa strony poszkodowanej do wyboru prawa właściwego, ponieważ takie rozwiązanie nie zapewniało dostatecznego stopnia przewidywalności rozstrzygnięcia. Założenia dopuszczały natomiast wybór prawa przez strony, pod warunkiem że nie naruszałby on praw osób trzecich. Twórcy założeń do konwencji przewidzieli ponadto szczególne zasady odnośnie do deliktów związanych z ruchem drogowym, transportem, produktami niebezpiecznymi, nieuczciwą konkurencją i praktykami ograniczającymi, naruszeniem środowiska oraz naruszeniem praw osobistych ${ }^{34}$.

Twórcy założeń do projektu odwrócili zatem koncepcję, na której opierała się konwencja EWG, to jest dania pierwszeństwa zasadzie prawa miejsca czynu powodującego szkodę oraz uzupełnienia jej bardzo szeroko ujętą klauzulą korekcyjną najściślejszego związku, co okazało się założeniem całkowicie błędnym. Zasada ta nie może bowiem funkcjonować jako główna, lecz jedynie jako klauzula wyjątkowa od innego łącznika. Dzieje się tak ze względu na to, że jest ona zbyt ogólna, a tym samym wprowadza zbyt duży stopień niepewności wskazania prawa dla stron sporu transgranicznego. Podsumowując, należy uznać, że twórcy projektu w zbyt dużym stopniu zainspirowali się koncepcjami kolizjonistyki amerykańskiej, mimo że powstały one na gruncie zupełnie innego systemu prawnego i w połowie lat dziewięćdziesiątych XX wieku zostały już dostatecznie zrewidowane przez praktykę.

\subsection{Propozycja Europejskiej Grupy ds. Prawa Prywatnego Międzynarodowego}

Jednocześnie z pracami w Radzie toczyły się prace w Komisji Europejskiej. W tym celu Komisja ufundowała program GROTIUS, w którym prace nad przyszłą konwencją prowadzone były przez Europejską Grupę ds. Prawa Prywatnego Międzynarodowego (GEDIP). GEDIP przyjął pierwszą wersję projektu konwencji o prawie właściwym zobowiązaniom pozaumownym w czerwcu 1998 roku. Dokument przewidywał oddzielne zasady co do pozaumownych zobowiązań wynikających ze zdarzeń powodujących szkodę oraz co do pozaumownych zobowiązań wynikających ze zdarzeń innych niż zdarzenia powodujące szkodę. Odnośnie do zobowiązań pozaumownych wynikających ze zdarzenia powodującego szkodę przewidziano ogólną zasadę, że prawem właściwym powinno być prawo państwa, z którym zobowiązanie pozaumowne jest najściślej związane, w połączeniu

34 Dokument Rady nr 9755/98 z dnia 15 lipca 1998 roku, s. 1-4. 
z (1) wzruszalnym domniemaniem na rzecz (a) prawa państwa wspólnego miejsca zwykłego pobytu sprawcy szkody i osoby poszkodowanej, alternatywnie (b) prawa państwa, w którym doszło do wystąpienia zarówno zdarzenia powodującego szkodę, jak i samej szkody, jak również z (2) specjalnymi domniemaniami w przypadku (a) naruszenia prywatności bądź praw osobowych, (b) nieuczciwej konkurencji bądź ograniczających praktyk handlowych i (c) szkody na środowisku ${ }^{35}$.

Co do zobowiązań pozaumownych wynikających ze zdarzenia innego niż zdarzenie powodujące szkodę przewidziano identyczną zasadę, z wzruszalnym domniemaniem na rzecz (1) prawa, które jest właściwe lub które byłoby właściwe odnośnie do istniejącego uprzednio (to jest przed wystąpieniem zdarzenia) bądź przyszłego związku, z którym związane jest zobowiązanie pozaumowne, alternatywnie (2) w przypadku zobowiązania dotyczącego zwrotu z tytułu bezpodstawnego wzbogacenia - prawa właściwego państwa, w którym doszło do wzbogacenia, i (3) w wypadku zobowiązania wynikającego z prowadzenia cudzych spraw bez zlecenia (negotiorum gestio) — prawa państwa zwykłego pobytu beneficjenta w momencie dojścia do wzbogacenia albo w przypadku ochrony osoby lub majątku osobistego - prawa państwa, w którym osoba lub majątek były usytuowane w momencie wzbogacenia. Strony mogły wybrać prawo właściwe zobowiązaniu pozaumownemu, ale tylko na podstawie wyraźnej umowy zawartej po powstaniu sporu i przy założeniu, że nie naruszy ona praw osób trzecich ${ }^{36}$.

Nie sposób nie zauważyć, że projekt GEDIP idzie w podobnym kierunku co wstępne założenia do konwencji opracowane przez Radę - obydwa dokumenty jako główną przyjmują bowiem zasadę prawa najściślejszego związku, z tą tylko różnicą, że propozycja GEDIP jest bardziej dopracowana pod kątem reguł interpretacyjnych, którymi należy się posługiwać przy stosowaniu zasady głównej, między innymi uwzględnia prawo miejsca wspólnego pobytu stron. Nie wydaje się natomiast, aby zabiegi te doprowadziły do znaczącego zwiększenia przewidywalności rezultatu albo do pewności prawa, zwłaszcza że te reguły interpretacyjne mają postać nie zasad, ale domniemań, które ponadto są wzruszalne ${ }^{37}$. W ten sposób projekt GEDIP prowadzi w rezultacie do tego samego celu co projekt Rady, a mianowicie do konieczności tworzenia na etapie stosowania tego aktu prawnego kolejnych wytycznych interpretacyjnych, które dodatkowo musiałyby być osadzone pomiędzy wzruszalnymi domniemaniami, co jeszcze bardziej komplikowałoby proces wskazywania prawa właściwego.

35 K.F. Kreuzer, op. cit., s. 20-21.

36 Ibidem.

37 Nie sposób się zatem w tym miejscu nie zgodzić ze stanowiskiem S.C. Symonidesa, że propozycja GEDIP to „elegancki, wyszukany i elastyczny dokument, który został zaprojektowany dla wyspecjalizowanych sędziów zdolnych do posługiwania się uznaniem niezbędnym do dokonywania wyważenia sądów” - idem, Rome II and tort conflict: A missed opportunity, „American Journal of Comparative Law" 56, 2008, s. 177 (tłum. M.W.-M.). 


\section{Uwspólnotowienie współpracy w sprawach cywilnych w traktacie amsterdamskim}

\subsection{Materialne podstawy prawne współpracy w sprawach cywilnych}

Nowe perspektywy odnośnie do prawa prywatnego międzynarodowego w Europie otworzyły się po podpisaniu 2 października 1997 roku traktatu amsterdamskiego $^{38}$, kiedy to współpraca sądowa w sprawach cywilnych została przesunięta do I filaru i objęta tytułem IV ${ }^{39}$ TWE, „Wizy, azyl, imigracja i inne polityki związane ze swobodnym przepływem osób" (art. 61-69). Jednocześnie poprzednia odpowiedzialność Unii Europejskiej za ten obszar została uchylona poprawką art. 29 (popr. K1) TUE, który teraz odnosił się tylko do współpracy policyjnej i sądowej w sprawach karnych ${ }^{40}$.

Artykuł 61 wymieniał enumeratywnie te dziedziny, w których odpowiednie środki zostaną przyjęte przez Radę i państwa członkowskie, z zastrzeżeniem, że powinno to być zrobione ,W celu stopniowego ustanowienia przestrzeni wolności, bezpieczeństwa i sprawiedliwości”. Na tej liście lit. c stanowiła o „środkach w dziedzinie współpracy sądowej w sprawach cywilnych przewidzianych w artykule $65 \% 41$. W art. 61 wyodrębniono zatem dwa rodzaje środków przyjmowa-

38 Traktat amsterdamski wszedł w życie dnia 1 maja 1999 roku, natomiast już w dniach 15 i 16 października 1999 roku w Tampere odbyło się specjalne posiedzenie Rady Europejskiej, na którym zostały podjęte kroki mające na celu rozwój współpracy państw europejskich w obszarze wolności, bezpieczeństwa i sprawiedliwości. Współpraca ta skupiła się na trzech głównych celach. Kluczowym zadaniem państw członkowskich było doprowadzenie do „swobodnego przepływu orzeczeń w sprawach cywilnych i handlowych", przede wszystkim przez zapewnienie wzajemnego uznawania i wykonywania orzeczeń z pominięciem ich merytorycznej kontroli. Kolejny cel to poprawienie dostępu do wymiaru sprawiedliwości poprzez utworzenie systemu informacyjnego dotyczącego zawiłości systemów prawnych poszczególnych państw członkowskich, opracowanie podręczników itp. Natomiast trzecie, najistotniejsze z punktu widzenia niniejszej rozprawy, zadanie podjęte w czasie szczytu w Tampere to kwestia ujednolicenia prawa w obrębie Wspólnoty dzięki opracowaniu nowych instrumentów ułatwiających współpracę sądową. Zob. Wspótpraca sądowa w Unii Europejskiej, red. I. Dzialuk, C. Michalczuk, M.S. Królak, Warszawa 2006, s. 21-22.

39 Kolejną kontrowersją wydaje się umiejscowienie przepisów uprawniających Wspólnotę do ujednolicania prawa prywatnego międzynarodowego w jednym tytule wraz z przepisami emigracyjnymi. Taki krok poskutkował protestem Danii, Irlandii i Wielkiej Brytanii, które wyłączyły się od współpracy w ramach tytułu IV, a Wielka Brytania i Irlandia zastrzegły przy tym możliwość włączenia się w tę współpracę tylko na zasadzie przystąpienia. To z kolei wywołało liczne kontrowersje u przedstawicieli doktryny, którzy uznali, że w tworzeniu wspólnych norm kolizyjnych powinny brać udział wszystkie państwa członkowskie. Zob. M. Fabjańska, M. Świerczyński, op. cit., s. 720-722.

40 J. Basedow, op. cit., s. 691-692.

41 Wersje skonsolidowane Traktatu o Unii Europejskiej i Traktatu ustanawiającego Wspólnotę Europejską (Dz.Urz. UE C 321 E z 29.12.2006, s. 1 n.). 
nych w celu ustanowienia przestrzeni wolności, bezpieczeństwa i sprawiedliwości, a kryteriami różnicującymi były: termin, w którym środki te miały być przyjęte, a także cel, jakiemu miały służyć. W grupie pierwszej znajdowały się środki, które miały zostać przyjęte w ciągu pięciu lat od chwili wejścia w życie traktatu amsterdamskiego, a więc do 1 maja 2004 roku, natomiast w grupie drugiej były to środki zmierzające do zapewnienia swobodnego przepływu osób zgodnie z postanowieniami art. 14, a także pewne środki towarzyszące, które były ze swobodnym przepływem osób bezpośrednio związane, wymienione w art. 61 lit. $a^{42}$. Artykuł 65 precyzował z kolei pojęcie „współpracy sądowej w sprawach cywilnych” i stanowił o ,współpracy sądowej w sprawach cywilnych mającej skutki transgraniczne w zakresie niezbędnym do należytego funkcjonowania wolnego rynku", a następnie wymieniał enumeratywnie trzy grupy zagadnień. Przepis ten był więc postrzegany nie jako samodzielna norma kompetencyjna, lecz norma wypełniająca normę kompetencyjną, którą jest art. 61 lit. c. Przepis ten wskazywał, co obejmują „środki z zakresu współpracy sądowej w sprawach cywilnych” i określał szczegółowe przesłanki wykonywania kompetencji przez Wspólnotę w tym zakresie ${ }^{43}$.

Odniesienie do klasycznego konfliktu norm występuje w lit. b: „wspieranie zgodności norm mających zastosowanie w państwach członkowskich w dziedzinie kolizji ustaw i sporów o właściwość". Co więcej, nie należy w tym kontekście zapominać, że lista zawarta w art. 65 nie była wyczerpująca. Dlatego też art. 65 nigdy nie pozwoliłby na przyjęcie środków, które nie mieszczą się w jednej z wymienionych kategorii, tak długo, dopóki nie zostałby one umieszczone w obszarze współpracy sądowej w sprawach cywilnych ${ }^{44}$. Z uwagi na to, że specjalne środki wymienione w pkt a do c artykułu 65 nie były w nim wskazane w sposób wyczerpujący, odniesienie w pkt b do środków „wspierania zgodności” norm kolizyjnych nie wykluczało z zakresu stosowania art. 65 środków ustanawiających jednolite normy kolizyjne ${ }^{45}$.

\section{2. Środki współpracy w sprawach cywilnych przewidziane w traktacie amsterdamskim}

Zgodnie z art. 249 ust. 1 i 3 TWE w celu wykonania swych zadań oraz na warunkach przewidzianych w niniejszym traktacie Parlament Europejski wspólnie z Radą i Komisją uchwalają rozporządzenia i dyrektywy, podejmują decyzje, a także wydają zalecenia i opinie. Rozporządzenie ma zasięg ogólny. Wiąże w całości i jest bezpośrednio stosowane we wszystkich państwach członkowskich. Dyrektywa wiąże każde państwo członkowskie, do którego jest kierowana, lecz

\footnotetext{
${ }^{42}$ K. Strąk, [w:] Komentarz do Traktatu..., t. 2, s. 145-146.

43 K. Weitz, [w:] ibidem, s. 202-203.

44 J. Basedow, op. cit., s. 705-706.

45 Opinia Służby Prawnej z dnia 2 marca 2004 roku, dokument Rady nr 7015/04.
} 
w odniesieniu do rezultatu, który ma zostać osiągnięty, pozostawia organom krajowym swobodę wyboru formy i środków ${ }^{46}$.

Dyrektywy są oparte na metodzie ustalania wiążących zasad dla krajowych systemów prawnych oraz są wiążące co do rezultatu, który ma zostać osiągnięty w każdym państwie członkowskim, do którego są adresowane, a zatem nie ma obowiązku w procesie implementacji przyjęcia tekstu opracowanego na poziomie europejskim. Jeśli rezultat, który ma zostać osiągnięty, jest zdefiniowany za pomocą precyzyjnych norm prawa prywatnego, w zasadniczej części wybór dla władz krajowych zajmujących się implementacją jest ograniczony. Jakkolwiek generalnie bezpośrednio stosowane normy prawa prywatnego pozostają narodowe w ich prawnym charakterze. W rezultacie Trybunał nie ma kompetencji do bezpośredniej interpretacji zharmonizowanych norm prawa krajowego.

Zastosowanie tego środka współpracy ma swoje wady i zalety. Do wad zalicza się niewątpliwie niebezpieczeństwo zagubienia celu procesu zbliżenia, jeśli postanowienia dyrektyw dotyczących prawa prywatnego nie są sformułowane w sposób precyzyjny lub zostawiają państwom członkowskim więcej swobody działania. Metoda dochodzenia do wspólnych elementów w prawie krajowym państw członkowskich drogą dyrektyw ma również niewątpliwie zalety, a mianowicie łączy ona stworzenie na poziomie wspólnotowym szeroko pojętych zasad — wzorów z jednoczesną kompetencją i odpowiedzialnością państw członkowskich do uchwalenia konkretnych i bezpośrednio stosowanych norm krajowych, które są adekwatne do specyficznego porządku prawnego (porządek ustawowy, orzecznictwo) i terminologii każdego z odnośnych państw.

$\mathrm{Z}$ kolei zgodnie $\mathrm{z}$ art. 249 ust. 2 rozporządzenie ma zasięg ogólny. Wiąże w całości i jest bezpośrednio stosowane we wszystkich państwach członkowskich ${ }^{47}$. Ten środek współpracy między państwami członkowskimi został ostatecznie wybrany przez twórców rozporządzenia „Rzym II”, a powody ku temu zostały jasno wyjaśnione w dokumentach legislacyjnych. Rozporządzenie ustanawia zunifikowane normy kolizyjne. Są one wystarczająco szczegółowe, precyzyjne i bezwarunkowe, a zatem nie wymagają od państw członkowskich żadnych środków w celu ich transpozycji do prawa krajowego. Są też samowykonalne. Istotą tych norm jest bezpośredni skutek celu, który został przed nimi postawiony, to znaczy zwiększenie pewności prawa i przewidywalności rozwiązań przyjętych w odniesieniu do wyboru prawa właściwego do danego rodzaju stosunku. Jeśli państwo członkowskie będzie miało możliwość manewru przy transpozycji tych norm do prawa krajowego, przywrócona zostanie niepewność prawa. Rozporządzenie jest z tego względu środkiem, który musi zostać wybrany w celu zagwarantowania ujednoliconego stosowania w państwach członkowskich ${ }^{48}$. Jedynym argumentem

46 Traktat Ustanawiający Wspólnotę Europejską (Dz.U. C 224/35 z 31.08.1992).

47 Ibidem.

48 Projekt rozporządzenia Parlamentu Europejskiego i Rady o prawie właściwym dla zobowiązań pozaumownych („,Rzym II”) (COM/2003/0427final-COD2003/0168). 
przemawiającym za tym środkiem współpracy było w zasadzie tylko to, że wciąż istnieją pomiędzy państwami członkowskimi poważne różnice odnośnie do norm kolizyjnych regulujących wskazanie prawa właściwego czynom niedozwolonym, w związku z czym przyjęcie środka wspólnotowego o ujednolicającym charakterze doprowadzi do ograniczenia autonomii państw członkowskich w tym zakresie ${ }^{49}$.

Mimo wejścia w życie w traktatu amsterdamskiego 1 maja 1999 roku grupa robocza Rady kontynuowała dyskusję nad proponowanym tekstem konwencji, a następnie już rozporządzenia, które ostatecznie przyjęło kształt, w jakim obowiązuje obecnie.

\section{Podsumowanie}

Reasumując, należy stwierdzić, że w początkowym okresie rozwoju współpracy w sprawach cywilnych jedyną jej formą była konwencja międzynarodowa. Współpraca w sprawach cywilnych leżała zatem w sferze prawa międzynarodowego publicznego. Forma konwencji międzynarodowej miała jednak wiele wad, przede wszystkim taką, że aby weszła w życie, wymagana była jej ratyfikacja przez określoną liczbę państw członkowskich, co rzadko kiedy się udawało. Ponadto zgodnie $\mathrm{z}$ zasadami przyjętymi w prawie międzynarodowym publicznym, przede wszystkim w Konwencji wiedeńskiej z dnia 23 maja 1969 roku o prawie traktatów ${ }^{50}$, istnieje szeroka możliwość składania zastrzeżeń do konwencji międzynarodowych, które to zastrzeżenia modyfikują prawa i obowiązki stron wobec siebie, a tym samym uniemożliwiają ich pełne ujednolicenie. Co więcej, żadne państwo nie ma obowiązku uczestniczenia w projektach mających na celu ujednolicenie prawa prywatnego. W rezultacie w wypadku zawierania poszczególnych konwencji w procesie tym mogą uczestniczyć różne państwa, co będzie tworzyć skomplikowaną i niekorzystną sytuację, patrząc z punktu widzenia wspólnego prawa prywatnego w Unii, polegającą na tym, że jedną konwencję będzie przyjmować jedna grupa państw, a drugą inna. Ponadto w przypadku interpretacji postanowień umów międzynarodowych z reguły nie jest zastrzeżona żadna obowiązkowa procedura mająca na celu ujednolicenie interpretacji i zastosowanie zasad i postanowień zawartych w traktacie. Wady te były przy tym wspólne bez względu na to, czy współpraca państw członkowskich miała miejsce na podstawie art. 220 TWE, czy też miała miejsce w tradycyjnej formie prawa międzynarodowego publicznego.

Nie powinno zatem dziwić, że w pierwszym okresie współpraca w sprawach cywilnych zatrzymała się tylko na etapie projektów. Z analizy projektowanych rozwiązań wynika jednak, że już na tym etapie ustaliła się lista łączników, które

49 C.W. Fröhlich, The Private International Law of Non-Contractual Obligationas According to the Rome II Regulation, Hamburg 2008, s. 24-25.

50 Dz.U. z 1990 r. Nr 74, poz. 439. 
znalazły zastosowanie w ostatecznej wersji rozporządzenia, z jednym wyjątkiem, że zamiast zasady lex loci delicti commissi zdecydowano się na zasadę lex loci damni. W konwencji państw Beneluxu przewidziano natomiast zastosowanie klauzuli najściślejszego związku, jak również łącznika wspólnego dla poszkodowanego i sprawcy szkody.

Z kolei Traktat z Maastricht ukonstytuował współpracę państw członkowskich w sprawach cywilnych, jednakże została ona włączona do III filaru, w związku z czym jedyną formą działania, poza tak zwanymi wspólnymi działaniami i wspólnym stanowiskiem, nadal pozostawała konwencja międzynarodowa. Zmiany wprowadzone przez Traktat z Maastricht miały w rzeczywistości znikomy wpływ na modyfikację warunków współpracy państw członkowskich w sprawach cywilnych. Przede wszystkim nie została wyeliminowana zasada jednomyślności wszystkich państw członkowskich, jako że sprzeciw jednego państwa mógł zniweczyć wszystkie wysiłki zmierzające do przyjęcia konwencji. Nic nie zmieniło również poszerzenie katalogu środków współpracy w sprawach cywilnych o wspólne stanowiska i wspólne działania. W przypadku wspólnych stanowisk nadal wymagana była jednomyślność, a ponadto nie był jasny ich charakter prawny, albowiem nigdzie nie zapisano wprost, że mają one moc wiążącą, co z kolei zostało wprost stwierdzone w wypadku wspólnych działań.

$\mathrm{W}$ okresie tym prace nad konwencją biegły dwutorowo. $\mathrm{Z}$ jednej strony toczyły się w obrębie Rady, a z drugiej strony - w obrębie powołanej przez Komisję grupy GEDIP, jednakże nie doprowadziły do żadnego znaczącego rezultatu, dopóki nie wszedł w życie traktat amsterdamski, który przewidywał nowe formy współpracy państw członkowskich w sprawach cywilnych. Współpraca ta została bowiem przeniesiona do I filaru, a więc do tej grupy zagadnień, których regulacja leżała całkowicie w gestii Wspólnoty. W związku z tym zakres dostępnych form współpracy poszerzył się o takie instrumenty jak dyrektywa i rozporządzenie, z których ostatecznie wybrano właśnie rozporządzenie, głównie ze względu na jego ujednolicający charakter, co w rezultacie doprowadziło do przyjęcia rozporządzenia „Rzym II” w obecnym kształcie.

\section{Bibliografia}

Basedow J., The communitarization of the conflict of laws under the Treaty of Amsterdam, „Common Market Law Review” 37, 2000.

Dickinson A., The Rome II Regulation: The Law Applicable to Non-Contractual Obligations, Oxford 2009.

Fabjańska M., Świerczyński M., Ujednolicenie norm kolizyjnych dotyczących zobowiąań pozaumownych, „Kwartalnik Prawa Prywatnego” 2004, nr 3.

Fröhlich C.W., The Private International Law of Non-Contractual Obligationas According to the Rome II Regulation, Hamburg 2008. 
Giuliano M., Lagrade P., Report on the Convention on the law applicable to contractual obligations, Dz.Urz. WE C 282 z 31.10.1980, s. 1-6.

Hoffman B. von, Lando O., Siehr K., European Private International Law of Obligations. Acts and Documents of an International Colloquium on the European Preliminary Draft Convention on the Law Applicable to Contractual and Non-Contractual Obligations, Tübingen 1975.

Komentarz do Traktatu ustanawiającego Wspólnotę Europejska, t. 1-3, red. A. Wróbel, Warszawa 2010.

Kreuzer K.F., Die Vergemeinschaftung des Kollisionsrechts für ausservertragliche Schuldverhältnisse (Rom II), [w:] Europäisches Kollisionsrecht, red. E. Jayme, Ch. Kohler, K. Kreuzer, K. Siehr, Wien 2004.

Meijers E.M., The Benelux Convention on private international law, „American Journal of Comparative Law" 2, 1953.

Müller-Graf P.C., EC Directives as a means of private law unification, [w:] Towards a European Civil Code, red. A. Hartkamp, M. Hesselink, E. Hondius, C. Joustra, E. du Perron, M. Veldman, Nijmegen 2004.

Nadelmann K.H., The EEC Draft of a Convention on the Law applicable to contractual and non-contractual obligations, „American Journal of Comparative Law” 2, 1973.

Nadelmann K.H., Impressionism and unification of law: The EEC Draft Convention on the Law applicable to contractual and non- contractual obligations, „American Journal of Comparative Law" 24, 1976.

Plender R., Wilderspin M., The European Private Law of Obligations, London 2009.

Saganek P., Wspótpraca $w$ dziedzinie wymiaru sprawiedliwości i spraw wewnętrznych, [w:] Integracja europejska. Wybrane problemy, red. D. Milczarek, A.Z. Nowak, Warszawa 2003.

Smits J., The Making of European Private Law, Antwerpen-Oxford-New York 2001.

Symonides S.C., Rome II and tort conflict: A missed opportunity, „American Journal of Comparative Law" 56, 2008.

Unia Europejska. Prawo instytucjonalne i gospodarcze, red. A. Grzelak, B. Wawrzyńczak-Jędryka, Warszawa 2005.

Wspótpraca sądowa w Unii Europejskiej, red. I. Dzialuk, C. Michalczuk, M.S. Królak, Warszawa 2006.

\section{Cooperation of EU member states in civil cases relating to the search for the applicable law for non-contractual obligations in 1957-1997}

\section{Summary}

The article focuses on a historical overview of the evolution of cooperation on civil matters in the European Union. Given the fact that this cooperation has developed the best in international private law, the author presents its development, using as her example legislative work on the harmonisation of conflict-of-law rules regarding tort, which in the end led to the adoption of the Rome II Regulation on the law applicable to non-contractual obligations. The article is divided into three parts corresponding to the stages in the development of cooperation between member states in civil matters - after the entry into force of the EEC Treaty, then after the entry into force of the Maastricht Treaty and finally the entry into force of the Treaty of Amsterdam.

Keywords: cooperation in civil cases, EEC Treaty, Maastricht Treaty, Treaty of Amsterdam, tort, private international law 


\title{
Die Zusammenarbeit der EU-Mitgliedstaaten betreffend Zivilsachen im Bereich der Feststellung des einschlägigen Rechtes für die außervertraglichen Verbindlichkeiten in den Jahren 1957-1997
}

\author{
Zusammenfassung
}

In dem Beitrag wird vor dem historischen Hintergrund dargestellt, wie sich die Zusammenarbeit betreffend Zivilsachen in der Europäischen Union ausgestaltet hat. Angesichts der Tatsache, dass sich diese Zusammenarbeit am besten im Bereich des internationalen Privatrechtes entwickelte, wurde ihre Entwicklung am Bespiel der gesetzgeberischen Arbeiten präsentiert, die schließlich zur Annahme der Verordnung Rom II über das für die außervertraglichen Verbindlichkeiten einschlägige Recht geführt haben. Der Beitrag besteht aus drei Teilen, die den Entwicklungstappen der Zusammenarbeit der Mitgliedstaaten im Bereich der Zivilsachen entsprechen — nach dem Inkrafttreten des EWG-Vertrages, dann des Vertrages von Maastricht und schließlich nach dem Inkrafttreten des Vertrages von Amsterdam.

Schlüsselwörter: Zusammenarbeit in Zivilsachen, Vertrag zur Gründung der Europäischen Wirtschaftsgemeinschaft (EWG-Vertrag), Vertrag von Maastricht, Vertrag von Amsterdam, unerlaubte Handlung, internationales Privatrecht 